\title{
Innovation, market power, and firm valuation
}

\author{
Hsien-Chang Kuo ${ }^{1 *}$ and Lie-Huey Wang ${ }^{2}$
${ }^{1}$ Department of Banking and Finance, Takming University of Science and Technology, 56, Section 1, Huanshan Rd., Neihu, Taipei 114, Taiwan, R.O.C.
${ }^{2}$ Department of Finance, Ming Chuan University, 250, Section 5, Zhong Shan N. Rd. Shihlin, Taipei 111, Taiwan, R.O.C.

Accepted 20 June, 2011

\begin{abstract}
The government's technology policy is an important guideline and direction for the development of technology industry in Taiwan. Taiwan government proposed a two-phase process of high-technology industrialization development and, established center-satellite factory system which has effectively enhanced cooperation on the dimension of business management, total quality management, technology transference, and financial support. This mechanism effectively upgrades the industry level and makes a significant contribution to Taiwan's economical miracle. This study adopts Olhson's (1995) model to explore the internal innovation of the information technology (IT) industry, from which it proceeds to observe the external behavior of the industry in terms of market power, in order to analyze how innovation and market power affect market value under keen competition. Empirical results show a positive correlation between innovation and market value of the IT industry, which indicates the importance of innovation to the development of firms and an explanatory capability outside the book values of firms. Market power indicates an insignificant correlation to market value except in small and medium-sized enterprises (SMEs), which implies the economic contribution of SMEs in Taiwan.
\end{abstract}

Key words: Innovation, market power, firm valuation, information technology, panel data.

\section{INTRODUCTION}

In an increasingly competitive global market, enterprises have to innovate to be able to survive and grow. Schumpeter (1939) develops the concept of entrepreneurial innovations, arguing that innovation is the crucial source of economic development and effective competition. Given the intense innovation competition today, the network of innovation in the form of strategic alliances/collaborative innovation has been viewed as an effective method to promote innovation diffusion (Daniel and Grigg, 2003; Horn, 2005). In national technology

*Corresponding author. E-mail: hckuo@ncnu.edu.tw,
hckuo@takming.edu.tw.

Abbreviations: IT, Information Technology; SMEs, Small and Medium-sized Enterprises; $\mathbf{R}$ and $\mathbf{D}$, research and development; CSDC, Corporate Synergy Development Center; MV, Market Value; BV, Book Value; NI, current net income MS, Market Share e, error item; $\boldsymbol{\beta} 1 \sim \boldsymbol{\beta}$, coefficient of independent variables. foresight programs, the government plays a sponsor role through the appropriate departments or ministries, which would enhance the country's ability to improve the competitive position for tomorrow (Wonglimpiyarat, 2006).

The primary goal of the Taiwan government in hightechnology industrial development since the early 1970 s has been to spur the growth of the information technology (IT) industry. As the IT industry has been the industry mainly responsible for Taiwan's fast economic growth in the last two decades. Taiwan's industrial and innovation systems are presented as humming machines of Industrial development. The public research institution-based science and technology industrial policy of Taiwan has been productive in helping the growth of private industry. The two-phase process of Taiwan's high-technology industrialization development is as follows: first, the government's research agencies acquire a technology from abroad, improve it and do most of the research and development ( $R$ and $D$ ) up to the level of a working prototype, and then infuse the industrial system with new technologies, or assist private firms with their own 
advanced $\mathrm{R}$ and D projects (Hong, 1997; Mathews and Cho, 2000; Amsden and Chu, 2003). Moreover, there are many government programs to finance industrial $R$ and $D$ that induces companies to concentrate on specific activities and favor certain business models over others, for example, the financing available to founders and companies in the developmental phases of their companies and the specific incentives provided by the Taiwanese system of financial regulations. Another example is the $R$ and $\mathrm{D}$ tax incentive program which specifies that the tax incentives are given to companies that control the whole production chain.

From the appreciation of the NT dollar in 1985 to the 1990s, when IT industry replaced traditional industry to become the mainstream industry in Taiwan, network linkage by basis of inter-industry and intra-industry has always been crucial to Taiwan's economical development and to the increment of corporate competitiveness. This is how Taiwan's electronics industry has now become indispensable in the global supply chain, making numerous firms worldwide suppliers. Taiwan established the Corporate Synergy Development Center (CSDC) in July 1984 , to accelerate the utilization of center-satellite factory system. It attempts to reorganize $97 \%$ of the small and medium-sized enterprises (SMEs) in Taiwan and the large firms that have cooperative relationship with SMEs. It does so by offering evaluation, consultation, socialization services, and long-term outsourcing contracts. In both vertical and horizontal integration, it has effectively enhanced cooperation on the dimension of business management, total quality management, technology transference, and financial support, effectively upgrading the industry. Under the guidance of CSDC, the centersatellite factory system has made a significant contribution to Taiwan's economical miracle.

With two decades of development, the Taiwan's IT industry has gradually completed its supply chain system and begun to take its place in global manufacturing. With economical growth brought about by technology, the knowledge-based economy has become the dynamics behind economical growth and competitiveness. What the contemporary market faces is no longer a domestic or regional environment, but a global village environment in which information is rapid and transparent. Technological advancement and market difference will play decisive roles for a niche formulation in the IT industry.

For the IT industry, information is ever-changing at an astonishing rate. Because of technological threshold and cultivation of human resources, the funding requirement is enormous. The product lifecycle also seems to be unpredictable, because it depends on market demand, which turns obsolete rapidly. These contribute to the variation of lifecycles of IT firms in the industry. Hence, $R$ and $D$ is a key factor to the growth of IT firms and the source of monopoly power and profit. Of course, the purpose of innovation is not only to increase competitiveness of the firms and to increase market value, but also to create new products through innovation activity.

Innovation refers to an inner process in firms. This inner activity is a display of autonomy and the process of the advancement of firms. As new products are released into the market, the popularity of the products increases the firm's business and market share, which betters the market power of the firm. This is the external activity of the firm on the market, which is capable of leading internal activities in the industry (Thomadakis, 1977). An issue worthy of concern in this study is whether this kind of external activity, displayed through the firm's inner activity in response to changes in the environment of the market, is capable of creating more value for the firms to increase their intangible assets.

The relationship between input and output in $R$ and $D$ is shown in Figure 1. In Figure 1, the firm inputs funds and then generates innovation activity; this is the inner process of the firm. The "black box" represents breakthroughs in new products or in new manufacturing processes, which bring about new commodities that attract consumers and are put to test in the supply demand chain of the market. The input in $R$ and $D$ brings about dynamic competition, which increases the competitiveness of the market. It is different from the traditional, static environment of price competition. Through technology from $R$ and $D$, the firms expect faster, more efficient, and less costly supply value that will replace the old organization, in order to acquire market superiority through the recognition of new commodities by the application of new technology in the market structure.

Chauvin and Hirschey (1993) depicts that innovation activities present a largely positive explanatory value toward firm value. This study focuses on Taiwan's IT firms from 1996 to 2003, which is the period in which Taiwan's IT industry grew from its initial stage into the growth stage, to explore the influences $R$ and $D$ activities and market power have on firm value. This is an integration of perspectives on internal innovation and external marketing and an attempt to explain IT firm value more completely, providing an analysis of the development of a successful industry. This study adopts Olhson's (1995) valuation model, with the exception of book value, to provide explanatory information on market value, to observe that internal $R$ and $D$ activity can provide firms explanatory information (other than book value) on firm value, and to check whether the performance of new commodities on the market shows a significant influence.

\section{The technology development scheme and policy in Taiwan}

Compared to other governments, the Taiwan government plays a more primary role in leading technological developments both in terms of financing researches by universities, public research institutes, and high technology firms and in terms of active participation in developing 


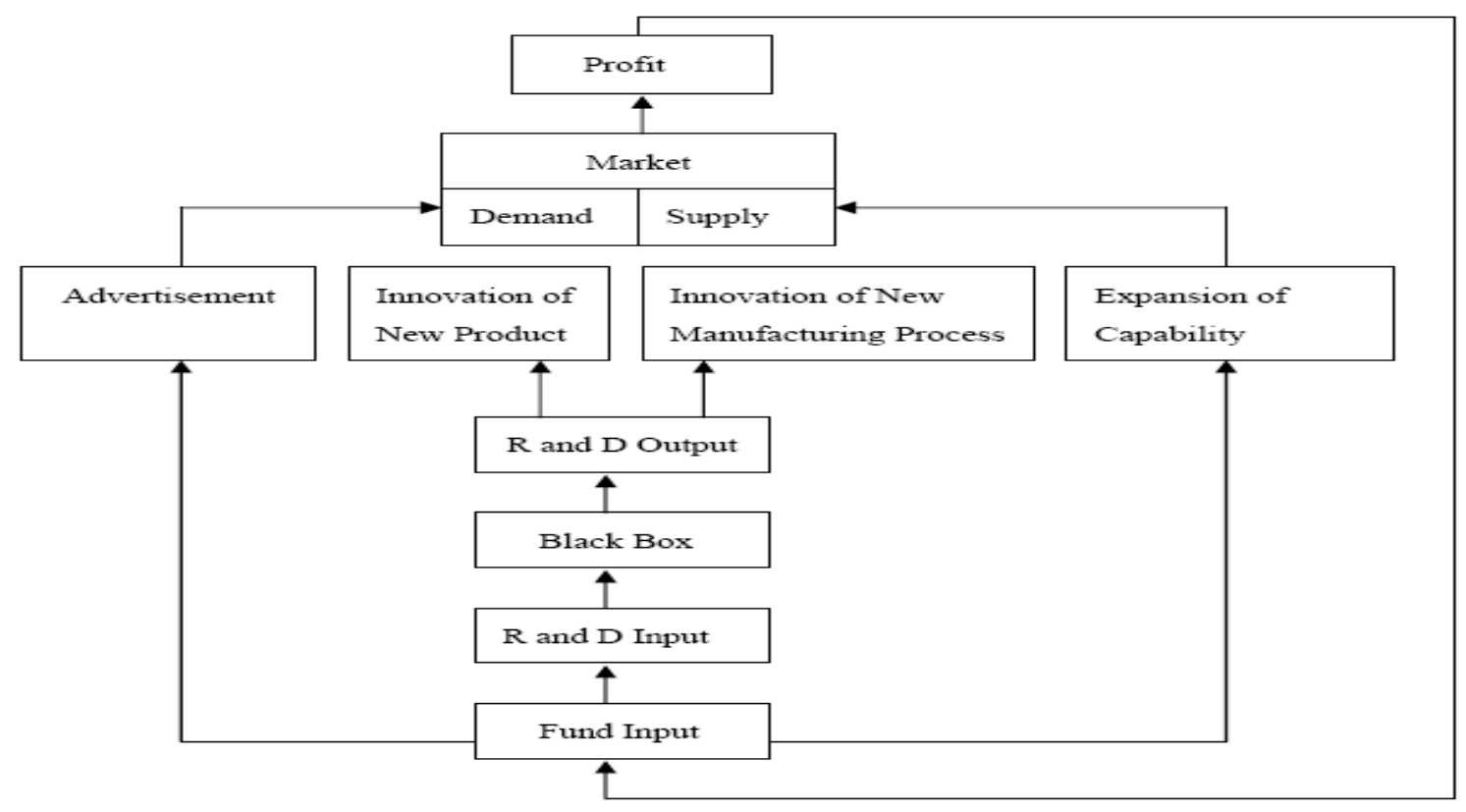

Figure 1. $R$ and $D$ input and output relationship.

Source: Economics Situation and Criticism, Vol. 9, Spring, 2003.

technology, providing infrastructures, resources, and risk sharing mechanisms for oversea technological talents to come to Taiwan to start new high-tech ventures.

In terms of technological support and industrial structure policies, the Taiwan government has continued to establish public research institutes directly and has controlled by the government in order to promote the development of high technology industry for more than 30 years. For example, the mission of Industrial Technology Research Institute is to obtain the technology of high potential products and manufacturing processes through technology transfer or through reverse engineering. In 1979, the government and a number of private enterprises jointly sponsored the Institute for Information Industry, which has become the think tank for the government on the development of the information industry, applications of information technology, and the establishment of the knowledge economy; the institute also assists the government in establishing the information technology industry, and in constructing the basis and the environment for a knowledge based economy; it also develops and introduces innovative information technology for new industrial opportunities. The Institute for Information Industry engages in research, development and introduction of software based information and communication technology. Through technology transfer and cooperative research supports the industries with the development of the latest software, to reduce the cost of research and the time of developing new products for domestic industries, and to promote the development of new industries and new markets. Furthermore, it created the "e-Taiwan Project" (a key component of the
"Challenge 2008" National Development Plan), and assisted in the planning of the M-Taiwan and U-Taiwan project for the government. Since the 1980s, the industry and the academia have collaborated to advocate high technology industry in Taiwan. The resultant "Hsinchu Science Park" established in December 1980 has attracted 396 high technology firms, including semiconductor industry, computer industry, communication industry, photonics industry, precision machinery industry and biotechnology industry. The interrelated industries are congregated to form a comprehensive upper, middle, and lower stream industrial structure. The Taiwan government has established Southern Taiwan Science Park and Central Taiwan Science Park respectively, and is actively expanding the foundations of Tongluo Science Park in Miaoli, Taoyuan Science Park, Hsinchu Biomedical Science Park, and llan Science Park. In 1984, was established to assist enterprises in forming centersatellite factory system in order to promote cooperation and synergy among the industries and to increase their competiveness in international markets. At the end of 1995, the Ministry of Economic Affairs, together with Council for Economical Planning and Development, National Science Council, and domestic information communication technology firms, co-founded "Office of Committee for Information Industry Development" to assist in the development of new products, to promote cooperation between industries, and to attract international technology and investment. In 2002, "Two Trillion Twin Star" industrial project was introduced with the expectation that the annual production value of both semiconductor and TFT-LCD industry can achieve 
breakthrough values of beyond one trillion NT Dollars. Industrial Development Bureau, Ministry of Economic Affairs, also founded Semiconductor Industry Promotion Office to actively develop Taiwan into a global semiconductor center in IC design, development, and manufacturing. In 2003, Ministry of Economic Affairs founded "Committee of Communication Industry Development" to promote and assist wireless communication, broadband international network, application service industry in establishing strategic alliances.

In terms of financial support policies, since 1979, the Taiwan government has continued to offer tax deduction for enterprises that have engaged in industrial $R$ and $D$. In 1988 and 1989 when Taiwan composite stock market index exceeded ten thousand points, a number of high technology firms began to go public or get listed. In 1991, in order to encourage private businesses to research and develop new leading products, to develop new ventures in high technology industry, to increase technology level, to reconfigure industrial structure, to increase international competitiveness, "Regulations for providing assistance in the development of new leading products" was established based on the third initiative "Accelerate the development of capital and technology intense Industries" from "Plan for accelerating upgrade and investment to the manufacturing industry" by Executive Yuan. The regulation provides government subsidy for private enterprises in order to share the research risk, to make the firms more compliant of national industrial development policy, to continue to input research and development resources and to cultivate research and development powers, to increase research and development capabilities and technology level, and to increase the competitiveness and the additional value of the industry. In addition, National Development Fund, from Executive Yuan, provides low interest loans for internet service industry, manufacturing industry, technology service industry, and logistics industry to engage in research and development or to increase their technological service capability. In 1991, "Enforcement rules of the statute for upgrading industries" was esta-blished to encourage the industries to engage in research and development, to create positive international brand images, to upgrade automatic equipments or technology, and anti-pollution equipments or technology, etc. Related investments and costs will be tax deductible for the shareholders. Meanwhile, new ventures in strategic high technology industry may opt for a five year tax holiday. In 1992, "Coordination Office of Investment Promotion" was established to finance private enterprises in major investments cases with investment capital exceeding two hundred million NT dollars.

Taiwan government proposed a two-phase technology industrial development policy which provides technological and financial support for IT industry, established center-satellite factory system which incorporates to promote cooperation and synergy among the IT industries, and founded science park in which the interrelated industries are congregated to form a comprehensive upper, middle, and lower stream industrial structure. The technology development scheme and policies of the Taiwan government have upgraded research and development capabilities and technology level, to increase the competitiveness and the additional value of the industry. In this study, the relationship between internal $R$ and $D$ innovation activities or external market power activities and Taiwanese listed IT firms' values were investigated.

\section{The value creation of $R$ and $D$ innovation and market power}

Firm value should not be represented only by book value. Intangible assets should be taken into account, that is, expectation of the operating performance of the firm in the future. However, the evaluation of intangible assets is the most difficult part. Hence, this study attempts through the influence that internal $R$ and $D$ innovation activity and external market share have on market value, to analyze the effects of the firm's innovation activity.

\section{Measurement for valuation}

Hirschey (1982) recognizes market value as the price the market is willing to pay that, determined by supplier and demander, represents the true value of the firm. Tomadakis (1977), Hirschey (1982, 1985), Keeley (1990), and Chauvin and Hirschey (1993) indicate the view that the book value represented in a financial statement is insufficient to represent the true value of the firm; the market value should be evaluated from tangible assets and intangible assets. Therefore, in addition to visible, tangible assets, an evaluation of intangible assets is indispensable in predicting prospective firm value. Roger (2001) refers to market value as the evaluating index of a firm's prospective performance, anticipating the profits in the future. A firm should increase activities that contribute to intangible assets to the best of its abilities. Under this, a number of scholars have evaluated market value to determine the true value of the firms (Griliches, 1981; Hirschey, 1985).

Academic studies most likely evaluating firm value follow the relative excess valuation method proposed by Tomadakis (1977), namely evaluating the book value divergence between market value and shareholder equity and then adopting sales as a deflator. Griliches (1981) applies Tobin's $Q$, which is the market value divided by the replacement cost of tangible assets, as the evaluation of a firm's value. Hirschey (1985) applies these two methods to explain the valuation mist of the book value in financial statements and to affirm that a firm's value should include tangible assets and intangible assets.

Both methods above actually explain the difference between market value and book value, the market's expectation on a firm's potential profit, and the mistake of 
evaluating only the tangible assets. Olhson (1995) proposes that the evaluation of a firm should not rely only on the book value in a financial statement which could be window dressing. Therefore, an appropriate evaluation of a firm, in addition to book value, should include other kinds of information with explanatory capability on market value. What Olhson (1995) proposes is no longer simply an explanation of the explanatory capability of intangible assets to market value, but an inclusion of the explanatory capability of other aspects; that is to say, as long as the information is capable of explaining market value, it should be taken into consideration to make the equity valuation model more complete.

\section{Analysis for innovation and market power}

Technological innovation and $R$ and $D$ innovation can stimulate the growth of the whole economical environment. Development of high technology not only contributes to conveniences in life, but also helps the firm's market structure to gain a better position and increases the competitiveness of the nation. Schumpeter (1942) proposes the concept of $R$ and $D$, maintaining that firms with a larger scale or better monopoly capability in their market structure - due to the scale of its finance competence, technology, and human resources - are more capable to engage in $R$ and $D$ innovation activities; the larger the scale of a firm is, the more active its $R$ and $D$ and innovation activities are; the more concentrated its market is, the more innovation activities the firm inputs.

Market structure tends to be related to the development of an industry. For Thomadakis (1977), market structure refers to a firm's existing assets and its expected value in the future. Link and Neufeld (1986) argue that there are two strategies in the market for the competition of commodities, innovation and imitation. The strategy a firm takes, innovation or imitation, depends on the position it currently has in the market structure and the capabilities of its competitors. A firm with monopoly power has more superiority compared to smaller firms and more capability to dominate the market. To take advantage of innovation means taking more input into $R$ and $D$ expenses, which represents the process of innovation. On the other hand, an imitation strategy has lower costs and lower risk. In terms of market competitiveness, however, innovation is superior for a firm as a market leader.

Roger (2001) proposes that innovation can be seen as an investment on future value, which increases the intangible assets of firms, with $R$ and $D$ expenses and patient rights of intellectual property as the proxy variables from innovation activities, considering innovation as an important factor to a firm's performance. This coincides with the empirical results by Chauvin and Hirschey (1993), indicating that R and D and advertisement expenditures are positively correlated with market value. $R$ and $D$ and advertisement expenditures can be seen as activities of investing in intangible assets, whereby intangible assets positively influence future cash flow.

The industrial environment is also a factor on the influences of innovation activities. Roger (2001) takes Australian firms as a research sample, and empirical result shows that, in comparison to the U.S., England, and other countries, the influence of $R$ and $D$ expenses have on market value is lower. This is identical to the point Cockburnz and Griliches (1988) propose. The difference in how $R$ and $D$ input is valued creates the difference in how much of the intangible asset is generated. The intangible asset brought about through $\mathrm{R}$ and $D$ expenses is influenced by the concept of storage capacity and depreciation rate. Hirschey (1992) holds the same view. The depreciation rate seems to be the deduction of intangible assets, that is to say, the decreasing effect of assets with time for intangible assets. However, there are no standards for the estimation of the depreciation rate. Therefore, there are different factors to have a significant influence on market value.

Montgomery (1985) considers market power as the capability of the participators of the market; this capability explains what influences price, quantity, and product. Sullivan (1974), Keehn (1980), and Berger and Hannan (1998) indicate market power as the ability to control the industry; a high market concentration indicates a high monopoly power, with a better ability to dominate the prices in the market, creating barriers for other firms in entering this industry. For Link and Neufeld (1986), whether a firm should apply an innovation strategy depends on if the firm has monopoly capability and larger innovation activities to reinforce its own superiority, to create obstacles for competitors, to enlarge market share, and to enhance market power.

Thomadakis (1977) proposes that the role of an enterprise in the market structure is explicit of the firm's power. Assets at present are generated from activities in the past; a firm's expected value in the future could come from the intangible assets. Therefore, the investment of an enterprise should focus on plans with a higher growth of future value. Thus, market share is used as the positioning advantage of an enterprise in the market structure of the industry; the better this advantage is, the more barriers to entry there are for other competitors, and such the firm will gain more than its rivals, abnormal returns will be bigger, and the firm's value will be more obvious. Hirschey (1985) applies market share, firm size, and market concentration as proxy variables for market structure. The result shows that there is indeed a significant relationship between the performance of market structure and market value.

\section{METHODS AND DATA}

\section{Panel data analysis}

This study applies both cross sectional and time series panel data. 
There are three distinct types of panel data. The first type is panel data with a constant intercept item, that is, the traditional regression model; the second type is a fixed effect model, its intercept varies over individuals; the third type is the random effect model or variance component model, and the intercept is random (Hsiao, 2003). Montgomery (1991) addresses that if the data refers to either the traditional regression model or fixed effect model of the same intercept, then its regression model's intercept will represent the characteristics of the individuals, but it is insufficient for representing the population. In a random effect model, however, where the intercept is a random sample from the population, its intercept presents the distribution of the population. The model is examined by adaptive statistics listed as follows:

\section{Traditional regression model}

As in the traditional classic regression model, there is a constant intercept, indicating the invariant characteristics of individual firms. If there are $i$ firms facing $t$ periods of panel data, the regression model will be:

$$
y_{i t}=\alpha+\sum_{k=1}^{K} \beta_{k} x_{k i t}+u_{i t} \quad i=1, \ldots, N \quad t=1, \ldots, T .
$$

\section{Fixed effect model}

If the intercept is different for each individual, then each individual will have a unique characteristic, and this regression model will also be a dummy variable model. The panel data regression can be represented by the following:

$$
y_{i t}=\alpha_{i}+\sum_{k=1}^{K} \beta_{k} x_{k i t}+u_{i t} \quad i=1, \ldots, N \quad t=1, \ldots, T .
$$

If the data type is a traditional regression model with a constant intercept or a fixed effect model, then examine it with the F-test: null hypothesis $H_{0}: \alpha_{1}=\alpha_{2}=\ldots . \alpha_{n}$; alternative hypothesis $\alpha_{i}$ not all equal $(i=1, \ldots N)$. The statistic $\mathrm{H}_{1}$ :

$$
F=\frac{R R S S-U R S S / N-1}{U R S S /[N T-N+K-1]} \sim F(N-1, N T-N-K+1),
$$

constant intercept, and URSS is the residual sum of squares of the fixed effect model. If $\mathrm{F}>\mathrm{F}(\mathrm{N}-1, \mathrm{NT}-\mathrm{N}-\mathrm{K}+1)$, then reject the null hypothesis, which means that the intercept of the fixed effect model is not all equal.

\section{Random effect model}

If the intercept is randomized, then it will not be related to the explanatory variable, and the model will be: $y_{i t}=\sum_{k=1}^{K} \beta_{k} x_{k i t}+v_{i t} v_{i t}=\alpha_{i}^{\prime}+u_{i t} i=1, \ldots, N_{t=1, \ldots, T}(3)$

where the intercept is $\alpha_{i}^{\prime} \sim\left(0, \sigma_{\alpha}^{2}\right)$, and the residual is $u_{i t} \sim\left(0, \sigma_{u i}^{2}\right)$.

examined data is a traditional regression model with a constant intercept or random effect model, then verify it with the LM (Lagrange multiplier) test, where null hypothesis $\mathrm{H}_{0}$ : all intercept is a constant $\left(\sigma_{\alpha}^{2}=0\right)$; alternative hypothesis $\mathrm{H}_{1}$ : intercept is random ( $\sigma_{\alpha}^{2}>0$ ). The statistic is

$\left.L M=N T / 2(T-1)\left[\sum_{n=1}^{N}\left[\sum_{t=1}^{T} \hat{u}_{i t}\right]^{2} / \sum_{n=1}^{N} \sum_{t=1}^{T} \hat{u}_{i t}^{2}\right]-1\right] \chi^{2}(1)$,

where $\hat{u}_{i t}$ is the residual estimated by the least square method.

To test the fixed effect model and random effect model, examine

then with Hausman's (1978) test, $\mathrm{H}_{0}: E \boldsymbol{\alpha}_{i} \mid \chi_{1 i t}, \ldots, \chi_{k i t} \equiv \alpha$; $\mathrm{H}_{1}: E \boldsymbol{\alpha}_{i} \mid \chi_{1 i t}, \ldots, \chi_{k i t} \neq \alpha$. The test statistics is $\omega=\hat{\beta}^{*}-\hat{\beta}^{\prime} \operatorname{Var}\left(\hat{\beta}^{*}\right)-\operatorname{Var}\left(\hat{\beta}^{\prime}\right)_{-}^{-1} \hat{\beta}^{*}-\hat{\beta}^{\prime} \simeq \chi^{2} k_{-}^{-}$ where $\hat{\beta}^{*}$ is the regression coefficient matrix estimated by the least square method, $\hat{\beta}^{\prime}$ is the estimation matrix from the random effect model, $\omega$ is the test statistic, and $\boldsymbol{x}^{2}=$ is $\mathrm{K}$ degrees of $\mathrm{Chi}$ Square test. If $\omega>\chi^{2}{ }_{--}^{-}$, then reject null hypothesis $\mathrm{H}_{0}$.

The Hausman's test is not a hypothesis test designed for the fixed effect and random effect models; the test mainly discusses the relationship between residual and explanatory variables, since, in the random effect model, its intercept is randomized, and the where RRSS is the residual sum of squares of the model with a variable will have no effect on explanatory variable. Therefore, if intercept and explanatory variables are statistically irrelevant, then apply the random effect model. On the other hand, if random intercept and independent variables are statistically correlated, then it means that the intercept is influenced by the explanatory variable, and then one applies the fixed effect model.

\section{The model}

This study incorporates innovation activities and market power into increasing the market value of firms based on Olhson's (1995) model; the valuation model of market value is as shown:

$$
M V_{i t}=\alpha_{i}+\beta_{1} B V_{i t}+\beta_{2} N I_{i t}+\beta_{3} R \& D_{i t}+\beta_{4} M S_{i t}+e_{i t}, \quad i=1, \cdots, N ; t=1, \cdots, T,
$$


Table 1. Descriptive statistics analysis.

\begin{tabular}{lccccc}
\hline Variable & Observation & Mean & Standard deviation & Minimum value & Maximum value \\
\hline Market value (MV) & 928 & 33,810 & 107,251 & 235 & $1,472,848$ \\
Book value (BV) & 928 & 11.200 & 27.700 & 244 & 329.000 \\
Current net income (NI) & 928 & 1,115 & 4,329 & $-19,800$ & 65,106 \\
R and D expenses & 928 & 414 & 1,066 & 0 & 12,700 \\
Market share (MS) & 928 & 0.56939 & 0.87799 & 0.00548 & 7.1876 \\
\hline
\end{tabular}

individual firm; $R$ and $D$, the research and development of the individual firm; $M S$, the market share of the individual firm; $e$, error item; $\alpha_{i}$ intercept; $\beta_{1 \sim} \beta_{2}$ coefficient of independent variables.

In this model the market value is the dependent variable, while the book value and current net income are the explanatory variables in the Olhson (1995) model. The explanatory variables are applied to observe how innovation activities and market power can derive the firm value are listed below. Research and development: this is the proxy variable for innovation activities, which indicates the degree of input into $R$ and $D$ of a firm, representing how the firm values are influenced by innovation activities. Market share: this study uses the market share of listed firms' operating revenue as the proxy variable for market power, as a representation of the monopoly power in the market.

\section{Data}

This study explores what the $R$ and $D$ innovation activities and market power of the IT industry have on firm value, with listed electronics companies in Taiwan as the sample data in our work. In fact, electronics companies are the mainstream in Taiwan's stock exchange market; it is also the main subject of foreign investment. This study employs 116 listed firms in the IT industry from the year 1996 to 2003, with a total of 928 observations.

The data are collected by time series and inter-firm data, and in panel data analysis; the financial statements come from the Taiwan Economic Journal Data Bank. Table 1 listed below provides a descriptive statistics analysis, in which the unit of MV, BV, NI, and R and D is NT\$ million; the market share is a percentage. From min value, max value, and standard deviation in the descriptive statistics analysis of the samples, this study finds out that there are significant differences in the market value, book value, current net income, $R$ and $D$ expenses, and market share of the research samples.

\section{RESULTS}

This purpose of this study is to evaluate if $R$ and $D$ activities in Taiwan's IT industry affect listed firms' value, and also if market share can be a factor to market value for the IT industry in the vital function as a global manufacturer. First, the study take 116 listed electronics firms as a sample to manipulate innovation activities and market power in the panel data. It then discuss if there are structural differences between firm size and $R$ and $D$ innovation activities.

\section{Analysis of the IT industry}

Model 1 is based on the Olhson (1995) model to discuss the market value of the firms. In addition to book value and current net income, we incorporate $R$ and $D$ and market share variables as more complete capable information for an adaptive market value.

As is shown in Table 2, the analysis of Model 1 is the fixed effect model. Empirical results show that, in the explanatory variables of the Olhson model, book value is positively correlated, while $R$ and $D$ is positively correlated under the significant level of $5 \%$, and market power is insignificant. As for innovation activities, Link and Neufeld (1986), Hirschey (1982), Chauvin and Hirschey (1993), and Roger (2001) refer to innovation activities as intangible assets, with research results showing a positive significance with market value. In this study, while the innovation proxy variable of $R$ and $D$ is significant, its coefficient with market value is only 0.0146 ; this could possibly be, because of the difference between the $R$ and $D$ input of Taiwan's IT firms and that of developed countries (Figure 2). In Figure 2, Taiwan's R and D input from 1991 to 2002 , US $\$ 12,246.6$ million, falls far behind that of the U.S. or Germany, and some distance behind that of Japan, France, England, or South Korea. This implies that there are still resources of input for domestic innovation activities for improvement, which will make the innovation value added be more than before.

$R$ and $D$ and firm value are positively significant, but the coefficient is less than previous research studies. For example, Hirschey (1985) and Cockburnz and Griliches (1988) also mention that against a different economic environment and market maturity both contribute to different results. In different countries, environments, industries, or times, the motivation for and the degree of a firm's engagement in $R$ and $D$ differ. As for the IT industry, the training of $R$ and $D$ human resources and other inputs in $R$ and $D$ are sunk costs, with uncertain future benefits, but innumerable intangible assets once they succeed.

What the high-tech industry focuses on is the knowhow of research; its technology level is high, and there is a barrier to entry, which is different from other industries. This means the innovation process of $R$ and $D$ creates the difference between firms, which then becomes a source of profit for the firms; this source, however, depends on the results from $R$ and $D$ activities. Therefore, the differentiation in the products from $\mathrm{R}$ and $D$ is the source of firm value. From the empirical result of 
Table 2. Empirical results.

\begin{tabular}{|c|c|c|c|}
\hline Variable & $\begin{array}{l}\text { Model } 1 \\
\text { (all firm) }\end{array}$ & $\begin{array}{c}\text { Model } 2 \\
\text { (SMEs) }\end{array}$ & $\begin{array}{c}\text { Model } 3 \\
\text { (large-sized firms) }\end{array}$ \\
\hline Book value (BV) & $\begin{array}{c}0.0026594^{* *} \\
(11.058)\end{array}$ & $\begin{array}{l}0.000116^{*} \\
(1.768)\end{array}$ & $\begin{array}{c}0.002703^{* *} \\
(7.871)\end{array}$ \\
\hline Current net income (NI) & $\begin{array}{c}-0.0008474 \\
(-1.117)\end{array}$ & $\begin{array}{c}0.0046623^{* *} \\
(11.001)\end{array}$ & $\begin{array}{c}-0.0009386 \\
(0.867)\end{array}$ \\
\hline$R$ and $D$ expenses & $\begin{array}{c}0.0146365^{\star *} \\
(2.765)\end{array}$ & $\begin{array}{l}0.0022324^{* *} \\
\quad(5.723)\end{array}$ & $\begin{array}{c}0.015366^{\star *} \\
(2.032)\end{array}$ \\
\hline Market share (MS) & $\begin{array}{l}661300 \\
(1.258)\end{array}$ & $\begin{array}{c}225509^{* *} \\
(5.935)\end{array}$ & $\begin{array}{l}638840 \\
(0.851)\end{array}$ \\
\hline $\begin{array}{l}\text { F-test } \\
{[P \text { value }]}\end{array}$ & $\begin{array}{c}3.51 \# \\
{[0.0000]}\end{array}$ & $\begin{array}{c}5.96 \\
{[0.0000]}\end{array}$ & $\begin{array}{c}3.46 \# \\
{[0.0000]}\end{array}$ \\
\hline LM-test & 1217.12 & 404.00\# & 1337.39 \\
\hline [P value] & {$[0.0000]$} & {$[0.0000]$} & {$[0.0000]$} \\
\hline $\begin{array}{l}\text { Hausman test } \\
{[\mathrm{P} \text { value] }}\end{array}$ & $\begin{array}{c}834.53 \\
{[0.0000]}\end{array}$ & $\begin{array}{c}2.55 \\
{[0.6364]}\end{array}$ & $\begin{array}{c}482.37 \\
{[0.0000]}\end{array}$ \\
\hline Number of observations & 928 & 464 & 464 \\
\hline $\mathrm{R}^{2}$ & 0.7277 & 0.5766 & 0.7085 \\
\hline
\end{tabular}

*, significant level at $0.1 ;{ }^{* *}$, significant level at 0.05 . \# in F-test row, fixed effect model; \# in LM-test row, random effect model where Model 1 and Model 3 are fixed effect models. In the fixed effect model, there is an independent intercept for each individual. Since there are many individuals, intercepts are omitted; Model 2 is the random effect model, and its intercept is random distribution.

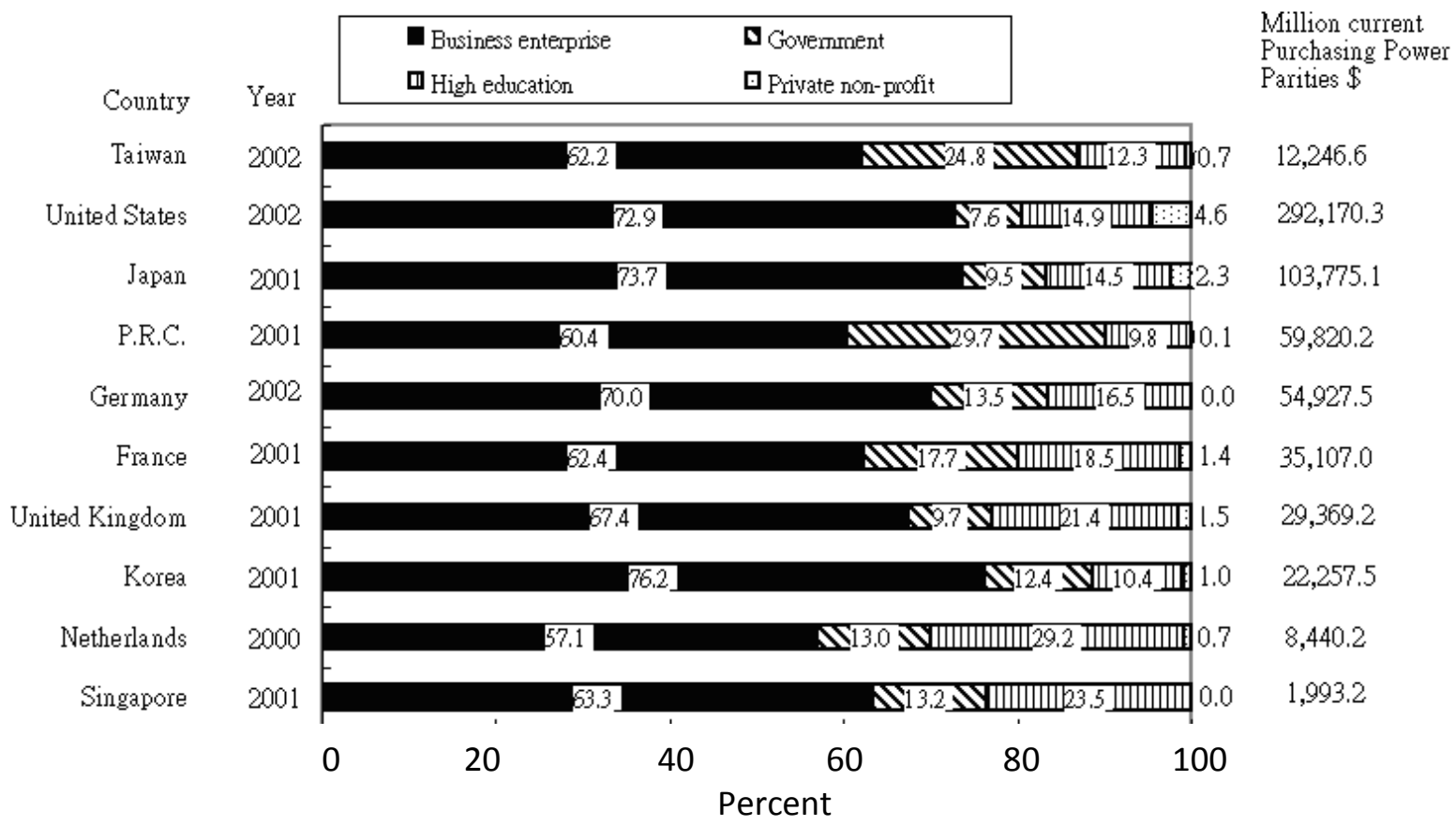

Figure 2. $R$ and $D$ expenses by department.

Source: Republic of China Science Technology Statistical Overview, 2003, p. 158. 
Model 1, market share is insignificant, indicating that the firm's market share is insufficient for bringing in value. What is important is gaining a profit base with differentiated technology. Schumpeter (1942) proposes the concept that a larger firm stays large, since the internal environment of the firm has acquired a technological advantage, with better product quality and lower production cost; it outperforms other firms at technology, which is why it has market power in the market structure.

\section{DISCUSSION}

Does firm size with its $R$ and $D$ expenses affect firm value? Schumpeter (1942) proposes that firms are the cycles of economies of scale; large-sized firms are more capable of innovation activities to obtain more advantage from technological innovation. Hicks (1935) consider that are under pressure to grow and to survive, which stimulates more flexible innovation activity. Hence, between SMEs and large-sized firms, how innovation activity affects the distinct size of firm value is also debated in this study.

Chauvin and Hirschey (1993) and Roger (2001) employ an operating revenue basis for categorizing firm size. This study also designates firm size based on operating revenue, to discuss the influence of firm size. Model 2 offers the empirical result for SMEs as shown in Table 2. The Hausman's test accepts the null hypothesis that the random effect model is more adaptable. In the explanatory variables, book value, current net income, and market value are positively significant. The influence of $R$ and $D$ expenses to market value is significant, indicating that the more innovation activity a firm has, the more beneficial it is to firm value.

Market share also shows a positive significance. Model 3 indicates the result of large-sized firms as shown in Table 2, with the model test adopted as the fixed effect model, which means that in terms of large-sized firms, there is an independent intercept for each firm. The performance of large-sized firms on market share does not affect market value. Results of Model 3 in Table 2 show that, among the explanatory variables, in addition to the significance of book value on market value, $R$ and $D$ is also a significant explanatory variable, indicating that innovation is valuable information toward explaining market value. From the empirical result we may find that in SMEs one can, in addition to $\mathrm{R}$ and $\mathrm{D}$, also consider the performance of market share. In large-sized firms, however, only innovation is significant, while market share is insignificant. Basically, in the sample structure of SMEs, their products are consumption equipments in the IT industry, with low-end technology; for example, Megamedia's product is mainly a floppy disk, CMC's main product is V8 videotape, D-Link's product is a wire box for a HUB, Chant World's main product is a multiple layered PCB and double layered PCB, Behavior Tech Computer's main product is a keyboard, etc. Since the main products of these firms have less innovative pressure compared to large-sized firms, there are limited barriers to entry, so that the firms focus their market competition on market share. Therefore, in addition to the enhancement from $\mathrm{R}$ and $D$ toward market value in SMEs, market structure also shows an emphasis on market share.

Large-sized firms are similar to the result from all electronics firms (Model 1). In terms of the $R$ and $D$ coefficient, the $R$ and $D$ coefficient of large-sized firms is 0.0154, while all electronics firms are 0.0146, with approximate coefficient results. This means that for the innovation activity of electronics firms in terms of Taiwan's environment, while innovation is a significant internal activity for high-tech firms, market share through the internal process is insignificant. This implies that $R$ and $D$ that could be profitable to IT firms depending on advanced technology, capable human resources, or smooth manufacturing processes.

As for the empirical result for IT firms, it is close to Schumpeter's (1942) conclusion that large-sized firms are more capable of $R$ and $D$ activity. In the recent development of Taiwan's IT industry, the capital market still focuses on the electronics industry as a key role for Taiwan's economy. For example, TSMC and UMC are the focus of corporate investment, which further empowers their efficient development of technology, to distinguish them from other firms with technological differences. SMEs, in addition to innovation, also emphasize on market share since their products are mostly consumption equipments. This is the distinction about innovation and market power between large-sized firms and SMEs in the IT industry.

\section{Conclusions}

With the coming of the age of the knowledge economy, Taiwan's industrial development has also entered a new era. The growth of its economy driven by technology is also the trend in Taiwan's economical development. The public research institution-based science and technology industrial policy of Taiwan has been enhanced in helping the growth of private industry. Taiwan government proposed a two-phase process of high-technology industrialization development and established centersatellite factory system, which has effectively induced cooperation on the dimension of business management, total quality management, technology transference, and financial support. With two decades of development, the IT industry on the island has gradually completed its supply chain system and begun to take its place in global manufacturing. Indeed, R and D is a key factor to the growth of IT firms and the source of monopoly and profit. Of course, the purpose of innovation is not only to increase the competitiveness of the firms and to increase market value, but also to create new products through innovation activity. As new products are released into the market, the popularity of the products increases the firm's 
business and market share, which betters the market power of the firm.

This paper adopts IT firms in Taiwan with 928 observations from 1996 to 2003, which is the period for when Taiwan's IT industry precisely grew from the initial stage to the growing stage. This study explores the market development of a knowledge-based economy, internal innovation activity, and external market share, in order to observe the magnitude of the market value of IT firms. The empirical result shows that innovation activity has a significant influence on the market value of IT firms, and that market share is insignificant toward market value, which implies that in the IT industry innovation is the source of profit; only through unceasing innovation can a firm survive in the market without being a failure. Categorizing IT firms by size, to further discuss market value, the study find that in SMEs, both innovation and market share are significant. From the sample structure of SMEs, we know that firms produce mostly low technology requirement consumption equipments; which is why market power is also a contribution. For large-sized firms, innovation is significant, indicating that large-sized firms are more capable of $\mathrm{R}$ and $\mathrm{D}$ to advance their competitiveness.

The development of information technology changes with each passing day. In a globalized market structure, how can a firm find its niche? In Taiwan, even though an IT firm's $R$ and $D$ inputs are less than developed countries, this study still finds that innovation plays a very important role for the development of enterprises, both for the present and for the future. Future studies may divide innovation resources by functions such as, for example, innovation capability of human resources, financial innovation capability, and sales innovation capability. This will provide more details for the explanation of a firm value.

\section{REFERENCES}

Amsden A, Chu WW (2003). Beyond Late Development Taiwan's Upgrading Policies. MIT Press: Cambridge, MA.

Berger AN, Hannan TH (1998). The Efficiency Cost of Market Power in the Banking Industry: A Test of the "Quiet Life" and Related Hypotheses. Rev. Econ. Stat., 80: 454-465.

Chauvin KW, Hirschey M (1993). Advertising, R\&D Expenditures and the Market Value of the Firm. Financ. Manage. 22:128-141.

Cockburnz I, Griliches Z (1988). Industry Effects and Appropriability Measures in the Stock Market's Valuation of R\&D and Patents. Am. Econ. Rev., 78: 419-423.
Daniel LJ, Grigg L (2003). Interorganisational Networks, Value Creation, and the Proocess of Technology Integration in Research and Development. Int. J. Technol. Policy Manage., 3(1): 95-111.

Griliches Z (1981). Market Value, R\&D, and Patents. Econ. Lett., 7: 183-187.

Hausman JA (1978). A Conditional Probit Model for Qualitative Choice: Discrete Decisions Recognizing Interdependence and Heterogeneous Preferences. Econometrica, 46: 403-426.

Hicks JR (1935). Annual Survey of Economic Theory: The Theory of Monopoly. Econometrica, 3: 8-27.

Hirschey M (1982). Market Power and Foreign Involvement by U.S Multinationals. Rev. Econ. Stat., 64: 343-348.

Hirschey M (1985). Market Structure and Market Value. J. Bus., 58: 8998.

Hirschey M (1992). Intangible Capital Aspects of Advertising and R\&D Expenditures. J. Ind. Econ. 4: 375-389.

Hong SG (1997). The Political Economy of Industrial Policy in East Asia: The semiconductor Industry in Taiwan and South Korean. Edward Elgar: Cambridge.

Horn PM (2005). The Changing Nature of Innovation. Res. Technol. Manage. J., 48(6): 28-31.

Hsiao C (2003). Analysis of Panel Data. New York: Cambridge University Press.

Keehn RH (1980). Market Power and Bank Lending: Some Evidence from Wisconsin 1870-1900. J. Econ. Hist., 40: 45-52.

Keeley MC (1990). Deposit Insurance, Risk, and Market Power in Banking. Am. Econ. Rev., 80:.1183-1200.

Link AN, Neufeld JL (1986). Innovation Versus Imitation: Investigating Alternative R\&D Strategies. Appl. Econ., 18:1359-1364.

Mathews AJ, Cho DS (2000). Tiger Technologies: The Creation of a Semiconductor Industry in East Asian. Cambridge University Press: Cambridge.

Montgomery CA (1985). Product-Market Diversification and Market Power. Acad. Manage. J., 28: 789-798.

Montgomery DC (1991). Design and Analysis of Experiments. New York: Wiley press.

Olhson JA (1995). Earnings, Book Value, and Dividends in Equity Valuation. Contemp. Account. Res., 11: 661-667.

Roger M (2001). Market Value, R\&D and Intellectual Property: An Empirical Analysis of Large Australian Firms. Econ. Rec.77: 323-337.

Schumpeter JA (1939). Business Cycles: A Theoretical. Historical and Statistical Analysis of the Capitalist Process. New York: McGraw-Hill. Vol. 2.

Schumpeter JA (1942). Capitalism, Socialism and Democracy Economic. New York: Harper and Brothers.

Sullivan TG (1974). Market Power, Profitability and Financial Leverage. J. Financ. 29: 1407-1414.

Thomadakis SB (1977). A Value-Based Test of Profitability and Market Structure. Rev. Econ. Stat., 59: 179-186.

Wonglimpiyarat $\mathrm{J}$ (2006). Technology Foresight: Creating the Future of Thailand's Industries. Foresight, 8(4): 23-33. 